\title{
Franchising and country development: evidence from 49 countries
}

\author{
Cintya Lanchimba \\ Escuela Politecnica Nacional, Quito, Ecuador and \\ CNRS, GATE Lyon-St Etienne, Université de Lyon, Lyon, France \\ Hugo Porras and Yasmin Salazar \\ Escuela Politecnica Nacional, Quito, Ecuador, and \\ Josef Windsperger \\ University of Vienna, Vienna, Austria
}

Franchising and country development

Received 12 July 2020 Revised 7 December 2020 12 February 2021 1 April 2021

Accepted 1 April 2021

\begin{abstract}
Purpose - Although previous research has examined the role of franchising for the economic development of countries, no empirical study to date has investigated the importance of franchising for social, infrastructural, and institutional development. The authors address this research gap by applying research results from the field of sustainable entrepreneurship and highlight that franchising has a positive impact on economic, social, institutional and infrastructural development.

Design/methodology/approach - This study uses a fixed-effects model on a panel dataset for 2006-2015 from 49 countries to test the hypothesis that franchising positively influences various dimensions of country development such as economic social institutional and infrastructural development.

Findings - The findings highlight that franchising has a positive impact on the economic, social, infrastructural, and institutional development of a country. Specifically, the results show that the earlier and the more franchising systems enter a country, the stronger the positive impact of franchising on the country's economic, social, institutional, and infrastructural development.

Research limitations/implications - This study has several limitations that provide directions for further research. First, the empirical investigation is limited by the characteristics of the data, which are composed of information from 49 countries (covering a period of 10 years). Because franchising is not recognized as a form of entrepreneurial governance in many emerging and developing countries, the available information is mainly provided by the franchise associations in the various countries. Hence, there is a need to collect additional data in each country and to include additional countries. Second, although the authors included developed and developing countries in the analysis, the authors could not differentiate between developed and developing countries when testing the hypotheses, because the database was not sufficiently complete. Third, future studies should analyze the causality issue between franchising and development more closely. The role of franchising in development may be changing depending on different unobserved country factors, economic sector characteristics, or development stages.

Practical implications - What are the practical implications of this study for the role of franchising in the development of emerging and developing economies? Because public policy in emerging and developing countries suffers from a lack of financial resources to improve the social, infrastructural and institutional environment, entrepreneurs, such as franchisors who expand into these countries, play an important role for these countries' development. In addition to their entrepreneurial role of exploring and exploiting profit opportunities, they are social, institutional, and political entrepreneurs who may positively influence country development (Schaltegger and Wagner, 2011; Shepard and Patzelt, 2011). Specifically, the findings highlight that countries with an older franchise sector (more years of franchise experience) may realize first-mover advantages and hence larger positive spillover effects on their economic, social, institutional and
\end{abstract}

(C) Cintya Lanchimba, Hugo Porras, Yasmin Salazar and Josef Windsperger. Published by Emerald Publishing Limited. This article is published under the Creative Commons Attribution (CC BY 4.0) licence. Anyone may reproduce, distribute, translate and create derivative works of this article (for both commercial and non-commercial purposes), subject to full attribution to the original publication and authors. The full terms of this licence may be seen at http://creativecommons.org/licences/by/4.0/ legalcode

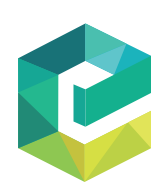

International Journal of Emerging Markets Emerald Publishing Limite
$1746-8809$ DOI 10.1108/IJOEM-07-2020-0779 
infrastructural development than countries with a younger franchise sector. Hence, governments of emerging and developing countries have the opportunity and responsibility to reduce potential market entry barriers and provide additional incentives for franchise systems in order to trigger these positive spillover effects. The authors expect that the spillover effects from the franchise sector on the economic, institutional, social and infrastructural development of a country are stronger in emerging and developing countries than in developed countries.

Originality/value - Previous research has focused on the impact of franchising on the economic development of a country, such as its growth of gross domestic product (GDP), employment, business skills, innovation and technology transfer. This study extends the existing literature by going beyond the impact of franchising on economic development: the results show that franchising as an entrepreneurial activity offers opportunities for economic, social, institutional, and infrastructural development, all of which are particularly important for emerging and developing economies. The findings of this study contribute to the international franchise and development economics literature by offering a better understanding of the impact of franchising on country development.

Keywords Franchising, Country development, Sustainable entrepreneurship, Panel data, Fixed effects model Paper type Research paper

\section{Introduction}

Why is entrepreneurship a significant variable in the development process?

Harvey Leibenstein (1968)

Franchising, as an entrepreneurial activity (Ketchen et al., 2011; Croonen et al., 2016), is based on a contractual relationship between two independent firms by which the franchisor allows the franchisee to use its brand name and business format in exchange for economic compensation in the form of royalties and upfront fees (Blair and Lafontaine, 2005). This governance form is present in many economic sectors and is internationally widespread. The franchisee's advantage results from using an established brand name, while the franchisor's advantage results from expanding its network by reducing the coordination and control costs in the local market. The majority of studies that focus on the international franchise business environment examine the firm-level determinants (resources, capabilities, agency and transaction costs) and macro-environmental determinants (economic, institutional and market financial conditions) of franchising as a market entry strategy (e.g. Jell-Ojobor and Windsperger, 2014; Rosado-Serrano et al., 2018; Alon et al., 2021). However, prior research has paid less attention to the role of franchising for country development (Kaufmann and Leibenstein, 1988; Choy and Goh, 1997; Alon and Banai, 2000; Alon, 2004, 2006; Michael, 2014). Hence, the aim of the study is to examine the role of franchising for the economic, social, institutional and infrastructural development of a country. Based on data from 49 countries, we show that franchising as an entrepreneurial activity offers an opportunity for economic, social, institutional and infrastructural development of a country.

Over the last few decades, numerous studies in the field of entrepreneurship and development economics have investigated the role of entrepreneurship for country and regional development (e.g. Wennekers and Thurik, 1999; Hessels and Naudé, 2017). In 1968, Leibenstein (1968, p. 72) asked the question "why [is] entrepreneurship a significant variable in the development process"? Entrepreneurship is considered a major driver of economic growth through employment, innovation, and technology transfer (Acs and Audretsch, 1988; Chwodhury et al., 2019). According to the "knowledge spillover theory of entrepreneurship" (Acs et al., 2009), entrepreneurship in a country or region results in "knowledge-spillover", generating positive externalities by increasing the stock of knowledge of incumbent firms and start-ups (Shepard and Patzelt, 2011). Furthermore, Li at al. (2006) argue that positive externalities also refer to the role of entrepreneurship in shaping laws, regulations and bureaucratic rules to improve the business environment (Hwang and Powell, 2006). 
Moreover, several studies in the field of sustainable entrepreneurship examine the importance of entrepreneurship for the environmental and social development of a country (e.g. Dean and McMullen, 2007; Shepard and Patzelt, 2011; Johnson and Schaltegger, 2020). Consequently, entrepreneurship plays an important role in the economic development as well as the social, institutional and environmental development of a country.

Although franchising is an important form of entrepreneurship, prior research has mainly discussed the entrepreneurial role of franchising for the economic development of a country. Most previous research has focused on the impact of franchising on the growth of GDP, employment, business skills, entrepreneurial capabilities, innovation and technology transfer (Kaufmann and Leibenstein, 1988; Stanworth et al., 2003; Christensen et al., 2010; Fredriks and Pennink, 2014). Few studies have analyzed the influence of franchising on specific aspects of the social, institutional and infrastructural development of a country. Alon and Banai (2000) and Alon $(2004,2006)$ argue that international franchisors may help to improve the institutional and physical infrastructure and have a positive impact on social development by improving the standard of living and education. Recently, studies on social and microfranchising (Montague, 2002; Alon et al., 2010; Du Toit, 2017; Naatu and Alon, 2019; Bretos et al., 2020; Naatu et al., 2020) show that the franchisor seeks to achieve social goals by using the format of commercial franchising. Social and micro-franchise networks may positively influence the social development of a country by improving healthcare services and alleviating poverty (e.g. Fairbourne et al., 2007). Consequently, although several studies have highlighted the positive influence of franchising on different aspects of the social, institutional and infrastructural development of a country, no paper has empirically examined the impact of franchising on economic, institutional, social and infrastructural development of a country using data from a larger number of countries.

To address this research gap, we analyze the effects of franchising on country development by applying a new development concept comprising the dimensions of economic, social, institutional, and infrastructural development. Our findings provide insights into the differences of the level of country development by applying a development concept that goes beyond the economic dimension. Specifically, we study the link between franchising and development by using panel data from 49 countries from 2006 to 2015, in order to test the impact of franchising on the economic, social, institutional and infrastructure development of a country. The results of this study contribute to the international franchising and development economics literature by showing that franchising as an entrepreneurial activity has not only a positive influence on the economic development, but also on the institutional, social and infrastructural development of a country.

This study proceeds as follows. The next section discusses the development concept and derives the hypotheses. The third section presents the empirical specifications using panel data from 49 countries from 2006 to 2015 on how franchising influences country development. Finally, the results are discussed and conclusions are drawn.

\section{Entrepreneurship through franchising and country development}

Dimensions of country development include areas such as economic, social, political, legal, and institutional structures, technology, the environment, religion and culture (Seers, 1969, 1972; Sumner and Tribe, 2008). However, traditional welfare economics considers development only from the perspective of its economic dimension by viewing economic growth measures through the lens of the GDP (Haque, 2004; Prieger et al., 2016). This was the dominant viewpoint until Sen (1980) - the Nobel prize-winning welfare economist - and the United Nations Development Programme (UNDP, 1990) widened this framework with the proposal that poverty involves a wider range of dimensions in terms of health, education, and living standards that are not captured by the economic dimension. Thus, the Human
Franchising and country development 
Development Index (HDI) was proposed by the United Nations Development Programme (UNDP, 1990). Anand and Sen (1994) argued that this indicator was developed in response to the need for a measure that fully represents human achievement in several basic areas other than income-based indices of growth. Therefore, this index aims to measure human development in different countries from a more comprehensive viewpoint by considering dimensions that go beyond economic factors and include social factors, such as life expectancy, education and standard of living.

However, HDI has been criticized because it does not effectively reflect all dimensions of human life (Kovecevic, 2011). For example, only GDP, as a proxy for a decent standard of living, reflects human development because of its link with economic development and its high correlation with the other dimensions of the HDI. Likewise, critics of the HDI have highlighted the arbitrariness of the weights given to each of the dimensions that it comprises and the quality and availability of data used for its calculation. As a response to the various criticisms, the UNDP has made some modifications to the methodology for calculating the HDI, which limits the data's comparability over time. Despite the criticisms of HDI, since its inception in 1990, it has become the standard method to operationalize and compare levels of country development. Hence, as an initial index to operationalize country development we use HDI to examine the impact of franchising on country development. In addition, because the influence of franchising on country development is broader than that of wealth, economic growth, health, and education, we use a second construct for country development that has a broader domain than HDI, covering the economic, social, institutional and infrastructural development of a country. This development concept is consistent with research results in the sustainable entrepreneurship theory (e.g. Dean and McMullen, 2007; Johnson and Schaltegger, 2020). According to this perspective, entrepreneurship plays not only an important role for the economic development of a country but also for its institutional, social and environmental development.

(1) Economic Development: The first dimension of development refers to the contribution of entrepreneurs to the economy (Van Praag and Versloot, 2008). Several authors have shown that entrepreneurial activities have a positive influence on economic development, both for the case of developed (e.g. Alon, 2004; Urbano and Aparicio, 2016) and developing countries (e.g. Christensen et al., 2010; Fredriks and Pennink, 2014; Prieger et al., 2016; Acs et al.,2018). This economic development is mainly due to the growth in economic output and employment in previously unexploited or unknown markets and technology transfer (Stanworth et al., 2003; Coulibaly et al., 2018). In the case of the franchise-growth relationship, Michael (2014) showed that the causality goes from franchising to the service sector's GDP. Kaufmann and Leibenstein (1988) argued that franchising is an entrepreneurial activity that contributes to the development of countries by transmitting knowledge, provided the system is adaptable to cultural diversity and the country's economic and legal environment. In another stream of literature, Goldman $(1974,1981)$ showed that the modernization of both local and international retail chains stimulates economic development.

(2) Social Development: In addition to the economic dimension, the social dimension such as health, education, standard of living, and housing - is also relevant for the country development. Social development, defined as the combination of technological, subsistence, organizational, and cultural accomplishments through which people reproduce and feed, clothe, and house themselves (Morris, 2010), appears alongside economic growth. Hence, economic growth and social development - despite being conceptually different - are interrelated (Sánchez and Prado, 2015) 
because (1) economic growth is a requirement for improving living standards (Rodrik, 2014) and (2) both factors together determine social progress, which is defined as the evolution of society (Haller, 2012). In this respect, Naudé (2013) and Dhari and Omri (2018)argue that entrepreneurship contributes to the well-being and development of people by stimulating social development.

(3) Institutional Development: Even if economic and social dimensions are directly associated with franchising, the quality of institutions - referring to regulatory, legal, and bureaucratic rules and contract law - is influenced by the development and importance of the entrepreneurial sector, such as the franchise sector in a country. Franchisors as "institutional entrepreneurs" (Li et al., 2006; Shepard and Patzelt, 2011) are especially important in the context of developing countries because they may generate positive externalities in terms of generally better business environments by triggering institutional changes, such as changes in regulatory, legal and bureaucratic rules (Hessels and Naudé, 2017).

(4) Infrastructural Development: The fourth dimension of development refers to the infrastructure of a country, such as telecommunication, transportation, energy and water infrastructure (e.g. broadband, Internet, railways, airports, ports, roads, canals, irrigation networks and power plants) (Prud'homme, 2005; Apurv and Uzma, 2020). Infrastructure facilitates connectivity, interaction and exchange of knowledge in the business environment of a country (Audretsch et al., 2015). Previous literature has mainly focused on the influence of infrastructure on entrepreneurship and growth (e.g. Cernich et al., 2011; Woolley, 2013), and there is a paucity of studies examining the impact of entrepreneurship on infrastructural development. The impact of entrepreneurship, such as franchising, on infrastructure projects depends on its importance for achieving competitive advantage in a country. For instance, retailers (e.g. franchisors) use their strong bargaining power to influence the realization of infrastructure projects when they expand their operations in a specific country or region (Goldman, 1981, 2001). Additionally, empirical evidence suggests that infrastructure has a positive effect on social development, for instance resulting in a reduction of poverty and inequality (Calderón and Servén, 2004; Sawada et al., 2014).

To summarize, franchising as an entrepreneurial activity generates both direct and indirect effects on country development. We hypothesize (H1) that franchising has a positive impact on four major dimensions of country development - economic, social, infrastructural, and institutional (see Figure 1). Hence, the following sub-hypotheses can be formulated:

H1a. Franchising positively influences the economic development of a country.

$H 1 b$. Franchising positively influences the social development of a country.

H1c. Franchising positively influences the institutional development of a country.

H1d. Franchising positively influences the infrastructural development of a country.

\section{Methodology}

\section{Data collection}

We constructed a panel database using several sources of data on franchising for the period 2006-2015, including the European Franchise Federation, the International Franchise Association, the Ibero-American Federation of Franchising, and the World Franchise Council, in addition to the franchise association of the countries, for the variables related with franchising (see Table 1). Additionally, we used data from the World Bank (WB), the World 


\section{IJOEM}

Figure 1.

Research model: country development through franchising

\section{Country Development}
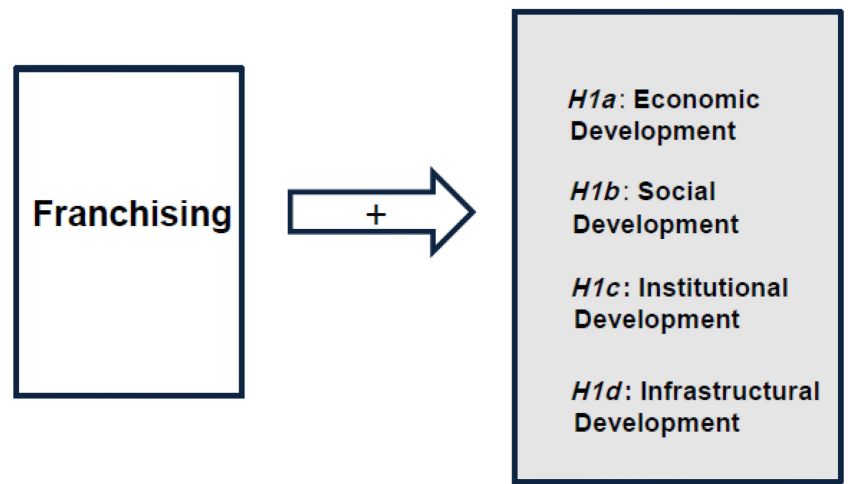

\begin{tabular}{ll}
\hline Countries* & Source \\
\hline
\end{tabular}

Argentina, Austria, Canada, China, Croatia, Czech Republic, Denmark, Finland, Greece, Hong Kong, Hungary, Italy, India, Japan, Mexico, Morocco, Netherlands, Philippines, Poland, Portugal, Russia, Singapore, South Africa, Spain, Slovenia, Sweden, Switzerland, United Kingdom, United States

Argentina, Austria, Brazil, Belgium, Canada, China, Denmark, Egypt, France, Finland, Germany, Hong Kong, Hungary, Italy, India, Indonesia, Japan, Mexico, Morocco, New Zealand, Poland, Portugal, Philippines, South Korea, Spain, Slovenia, Singapore, South Africa, Turkey, Ukraine

Austria, Belgium, Egypt, Germany, Hungary, New Zealand, Russia, Slovenia, Sweden, Switzerland, Singapore

Ecuador, Guatemala, Peru, Uruguay, Venezuela

Canada, Colombia, Sweden

Australia

Argentina

Brazil

Italy

Costa Rica

Table 1.

Chile

Note(s): *Some countries are mentioned more than once due to the combination of different data sources for different years
European Franchise Federation

French Franchise Federation

World Franchise Council

Ibero-American Federation of

Franchising

U.S. Commercial service

Griffith University

Asociación Argentina de

Franquicias

Associação Brasileira de

Franchising

Italian Franchise Association

Cámara de Comercio Costa Rica University of Chile
Variables regarding franchising

Trade Organization, the Standardized World Income Inequality Database (Solt, 2016), and the DLA Piper Global Law Firm for the variables related with the four dimensions of the Country Development Index. Table 2 presents a description of each variable and the data source.

The sample of countries selected for this study was based on two criteria: the availability of variables related to development and their heterogeneity in development terms. The countries' levels of development were considered according to the classification criteria of the UNDP, which is found in the annual Human Development Report (UNDP, 20062015). Because countries with lower development levels have more information availability 
Variable

Economic variables

GDP per capita expressed in constant 2010 dollars

Net FDI in current dollars

Inflation

External balance on goods and services as percentage of GDP*

Industry, value added as percentage of GDP

Services, value added as percentage of GDP

Social variables

Adolescent fertility

Employment in agriculture as percentage of total employment Employment in services as percentage of total employment

Female employment (ILO estimate)

Gross enrollment rate on primary level of education

Gross enrollment rate on secondary level of education

Gross enrollment rate on tertiary level of education

Infant mortality (per 1,000 births)

Life expectancy

Public expense as percentage of GDP

External debt per capita

Gini index

\section{Infrastructural variables}

Electric power consumption per capita

Improved water source as percentage of population with access Cellphone subscriptions

Fixed broadband subscriptions

Quality of port infrastructure

\section{Institutional variables}

Control of corruption, which captures the perception of the extent to which public power is exercised for private gain

Government effectiveness, which captures the perception of the quality of public services, civil service, and policy formulation, and the implementation and credibility of the government's commitment to such policies

Political stability and absence of violence/terrorism as a perception of the likelihood of political instability and/or politically motivated violence, including terrorism

Regulatory quality, which captures perceptions of the ability of the government to formulate and implement sound policies and regulations that permit and promote private sector development Rule of law as the perception of the extent to which agents have confidence in and abide by the rules of society

Voice and accountability as the perception of the extent to which a country's citizens are able to participate in selecting their government

Days required to start a business

Franchising law: Ordinal variable. It takes the value of 0 if the country does not have a disclosure law, relationship law, or registration law for franchising. It takes the value of 1 if there exists only a disclosure law and 2 if there exists only a relationship law. It takes the value of 3 if two of the three laws exist, and it takes the value of 4 if the three laws exist

Note(s): *Obtained from the World Trade Organization through the data collected by the World Bank
Franchising and country development

World Bank (https://data.worldbank.org/ indicator)

World Bank

Standardized World Income Inequality

Database (SWIID) (https://fsolt.org/swiid/)

World Bank

World Bank

DLA Piper Global Law Firm (https://www. dlapiper.com)

Table 2.

Variables used for DI 
problems, we faced difficulties in generating a larger sample. The final sample comprised 30 countries with a very high human development level (Argentina, Australia, Austria, Belgium, Canada, Chile, Croatia, Czech Republic, Denmark, Finland, France, Germany, Greece, Hong Kong, Hungary, Italy, Japan, South Korea, the Netherlands, New Zealand, Poland, Portugal, Russia, Singapore, Slovenia, Spain, Sweden, Switzerland, the United Kingdom, and the United States); 12 with a high human development level (Brazil, China, Colombia, Costa Rica, Ecuador, Malaysia, Mexico, Peru, Turkey, Ukraine, Uruguay, and Venezuela); and 7 with a medium human development level (Egypt, Guatemala, India, Indonesia, Morocco, the Philippines, and South Africa). This sample includes cases in which it was necessary to resort to other sources of information to fill in missing values, such as the franchise associations from each country. Therefore, our dataset comprised 49 countries, with data from 2006 to 2015 .

\section{Measurement}

Dependent variable: country development index. Based on our research model (see Figure 1), the dependent variable for testing our hypotheses is country development, measured by the Development Index (DI). The DI is a formative construct (Bollen and Lenox, 1991; Diamantopoulos and Winklhofer, 2001; Diamantopoulos et al., 2008) that is a composite of four dimensions: economic, social, infrastructural, and institutional development. Therefore, it is important to note that the domain of the content of the construct is primarily based on theoretical reasoning (Fayers et al., 1997; Stadler et al., 2021). The main difference between HDI and our DI is that the latter incorporates, in addition to the social and economic dimensions, the institutional and infrastructural dimensions.

For the operationalization of the economic dimension of country development we considered the following variables, which represent both the internal and external context of each country: the GDP (Sadequl, 1995; Islam and Clarke, 2002; Brinkman and Brinkman, 2011), inflation (Bruno and Easterly, 1998; Umaru et al., 2012), investment (Hermes and Lensik, 2003; Moran, 2012), external balance (Michelis and George, 2004), and external debt (Ajayi and Oke, 2012). The indicators reflecting the social component are as follows: the labor market situation (Taner et al., 2011), schooling (Chabbot and Ramirez, 2000; McGrath, 2010; Algraini, 2019), health (Ruger, 2003), and inequality (Anand and Kanbur, 1993; Salama, 2009; Stewart and Samman, 2014).

Additionally, we included the following variables to operationalize the institutional development of a country: control of corruption (Mungiu and Harmann, 2019), government effectiveness (Ahmad and Saleem, 2014), political stability (Waterbury, 1976; Altun, 2016) and absence of violence (Buvinic and Morrison, 1999; Bowman et al., 2008), regulatory quality and rule of law (Boettke and Subrick, 2003; Ganegodage et al., 2017), and voice and accountability (Goetz and Jenkins, 2002). We also used directly related institutional parameters for franchising, such as specific laws and the number of days required to start a business. Finally, we considered variables related to infrastructure, such as access to electricity and water, fixed broadband access, and cellphone subscriptions (Ganegodage et al., 2017).

The data cleaning process revealed that no variable had missing values exceeding $15 \%$. Because information for some of the variables, such as employment composition, education enrollment, inequality, and infrastructure, was not available for 2015, we extrapolated it using information from the previous years [1]. We performed pertinence analysis by looking at the correlation matrix determinant, which confirmed that the technique was adequate. The variables were standardized (excluding the governance variables, reported as standardized by the World Bank) in order to directly combine them. The minimum value of the Kaiser- 
Meyer-Olkin (KMO) statistic was 74.16 for 2010, and the highest was 81.78 for 2009; these represent commonly accepted values. Finally, we obtained the DI.

Before testing the hypotheses, we compare the country development results for HDI and our country development index (DI). To make this comparison possible, DI was normalized; therefore, the values presented are between 0 and 1 . Table 3 and Figure 2 present the comparison of the two indexes for 2015. The average difference (in absolute value) in the index ranking is three places. Despite Spearman's rank correlation coefficient $(\rho)=0.94$ reflecting that two indicators share a similar trend, differences in the ranking positions of the countries exist.

The largest number of matches in the two rankings is concentrated in countries that are located at the lowest positions - i.e. Poland (POL), Hungary (HUN), Turkey (TUR), Guatemala (GTM), and India (IND) - while in the highest positions, only Denmark (DNK) retains the fourth position in both rankings. Venezuela (VEN) falls 14 positions with respect to the HDI ranking. This result reflects the low performance of this country with respect to its institutional factors. The same also affects the performance of other Latin American countries, such as Ecuador (ECU) and Argentina (ARG), which fell two and four positions, respectively. By contrast, with respect to the HDI, Finland (FIN) moved up 14 positions because its institutional component had one of the highest values of all the countries studied. Similar results were found for other years. These differences show that the inclusion of institutional and infrastructural dimensions in DI can lead to variations in the development outcomes of various countries. Therefore, our DI evaluates more development aspects than the HDI.

Independent variables. To test our hypothesis that franchising positively influences country development, we used two different independent variables: the extensive and intensive margins of franchising. Extensive and intensive margins as measure of the extent and intensity of using a resource are widely applied in the labor market, development economics and world trade literature (e.g. Besedes and Prusa, 2011; Blundell et al., 2011, 2013; Mamo et al., 2019). For instance, the number of workers or export relations a year are used as a measure for extensive margin, and the number of average working hours or average value of an export relationship for intensive margin. Our variables extensive and intensive margin of franchising are adapted from the development literature that - to the best of our knowledge have not been used in franchising yet. We calculated a $z$-score of two variables for each margin and then averaged them.

Extensive margin of franchising. "Extensive margin" is conceptualized as the extent to which franchising has been used in a country. This variable is measured by combining the age of the franchising sector and the age of the franchising association of a particular country, defined as:

(1) Age of association: The difference between the year of study and the year of establishment of the association in the country.

(2) Age of first franchise: Defined as the difference between the year of study and the year of establishment of the first franchise in the country.

Intensive margin of franchising. "Intensive margin" is conceptualized as the intensity to which franchising is used. This variable is measured by combining the following two variables:

(1) Brands per capita: Defined as the existing number of brands in a country per inhabitant.

(2) Turnover per unit: The volume of sales of brands in a country in billion USD, per point of sale.
Franchising and country development




IJOEM

\begin{tabular}{|c|c|c|c|c|}
\hline Country & HDI & DI & $\begin{array}{c}\text { Ranking } \\
\text { HDI }\end{array}$ & $\begin{array}{c}\text { Ranking } \\
\text { DI }\end{array}$ \\
\hline Netherlands & 0.92 & 1 & 6 & 1 \\
\hline Singapore & 0.93 & 0.98 & 5 & 2 \\
\hline Finland & 0.9 & 0.96 & 17 & 3 \\
\hline Denmark & 0.93 & 0.96 & 4 & 4 \\
\hline Hong Kong China & 0.92 & 0.94 & 9 & 5 \\
\hline Switzerland & 0.94 & 0.94 & 2 & 6 \\
\hline Sweden & 0.91 & 0.91 & 11 & 7 \\
\hline Belgium & 0.9 & 0.89 & 16 & 8 \\
\hline Canada & 0.92 & 0.89 & 7 & 9 \\
\hline United Kingdom & 0.91 & 0.88 & 12 & 10 \\
\hline Australia & 0.94 & 0.85 & 1 & 11 \\
\hline New Zealand & 0.92 & 0.85 & 10 & 12 \\
\hline United States & 0.92 & 0.84 & 8 & 13 \\
\hline France & 0.9 & 0.82 & 15 & 14 \\
\hline Germany & 0.93 & 0.82 & 3 & 15 \\
\hline Austria & 0.89 & 0.82 & 18 & 16 \\
\hline Japan & 0.9 & 0.8 & 13 & 17 \\
\hline Spain & 0.88 & 0.74 & 21 & 18 \\
\hline Portugal & 0.84 & 0.72 & 26 & 19 \\
\hline Korea, Rep & 0.9 & 0.71 & 14 & 20 \\
\hline Slovenia & 0.89 & 0.68 & 19 & 21 \\
\hline Italy & 0.89 & 0.66 & 20 & 22 \\
\hline Greece & 0.87 & 0.64 & 23 & 23 \\
\hline Chile & 0.85 & 0.62 & 25 & 24 \\
\hline Czech Republic & 0.88 & 0.62 & 22 & 25 \\
\hline Poland & 0.86 & 0.57 & 24 & 26 \\
\hline Hungary & 0.84 & 0.56 & 27 & 27 \\
\hline Croatia & 0.83 & 0.56 & 29 & 28 \\
\hline Uruguay & 0.8 & 0.54 & 31 & 29 \\
\hline Costa Rica & 0.78 & 0.47 & 33 & 30 \\
\hline Malaysia & 0.79 & 0.44 & 32 & 31 \\
\hline Argentina & 0.83 & 0.43 & 28 & 32 \\
\hline Russian Federation & 0.8 & 0.41 & 30 & 33 \\
\hline Turkey & 0.77 & 0.36 & 34 & 34 \\
\hline Brazil & 0.75 & 0.33 & 37 & 35 \\
\hline Mexico & 0.76 & 0.31 & 36 & 36 \\
\hline China & 0.74 & 0.28 & 41 & 37 \\
\hline Peru & 0.74 & 0.26 & 39 & 38 \\
\hline South Africa & 0.67 & 0.25 & 46 & 39 \\
\hline Ukraine & 0.74 & 0.25 & 38 & 40 \\
\hline Colombia & 0.73 & 0.25 & 42 & 41 \\
\hline Ecuador & 0.74 & 0.15 & 40 & 42 \\
\hline Morocco & 0.65 & 0.11 & 47 & 43 \\
\hline Philippines & 0.68 & 0.1 & 45 & 44 \\
\hline India & 0.62 & 0.09 & 49 & 45 \\
\hline Guatemala & 0.64 & 0.05 & 48 & 46 \\
\hline Egypt & 0.69 & 0.05 & 43 & 47 \\
\hline Indonesia & 0.69 & 0.05 & 44 & 48 \\
\hline Venezuela & 0.77 & 0 & 35 & 49 \\
\hline
\end{tabular}




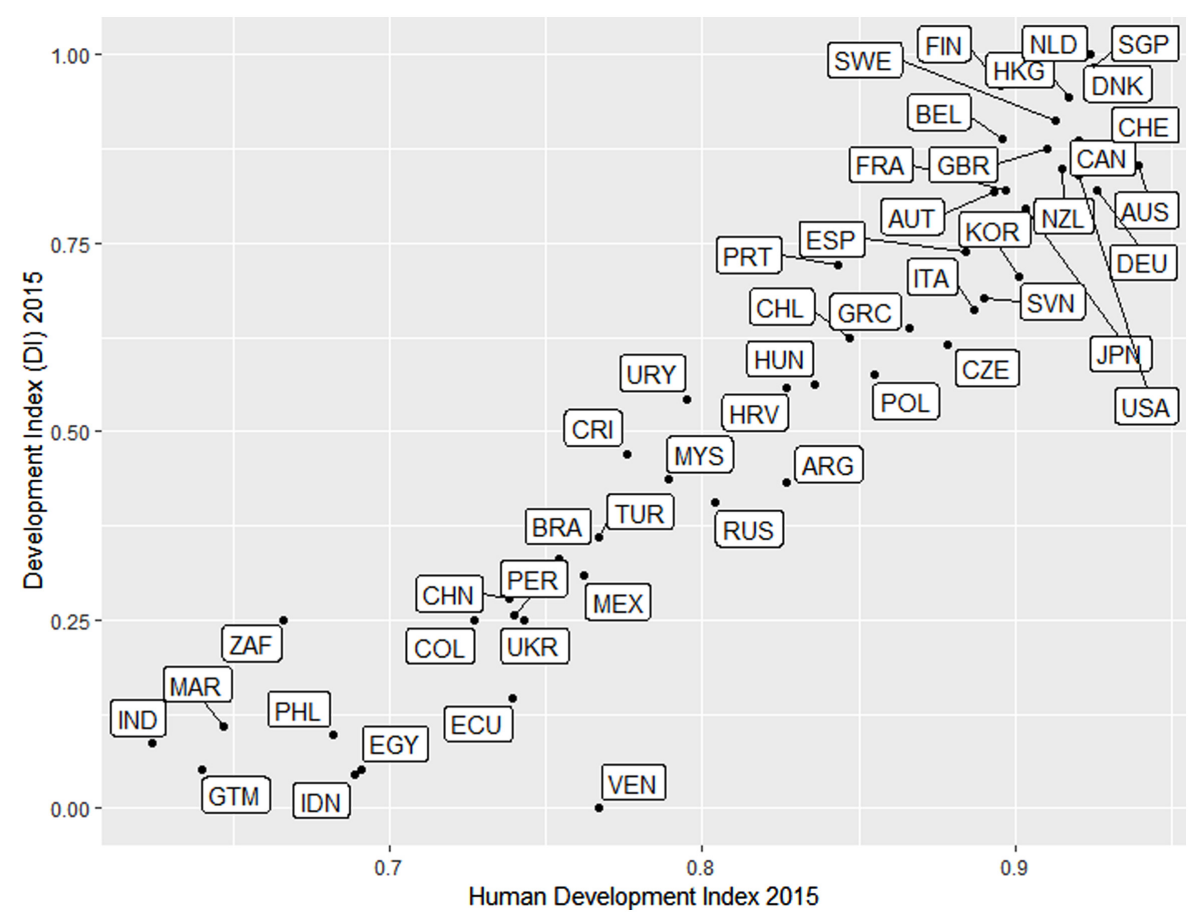

Franchising and country development

Figure 2. HDI versus DI: 2015

Control variables. To control for the different effects of the existing proportion of national and international franchisors in each country on development, we use the following control variable: domestic brands percentage, defined as the percentage of locally born brands compared with the total brands present in the country.

\section{Empirical analysis}

Descriptive statistics

Tables 4 and 5 report the means and standard deviations and the correlation matrix, respectively, for the selected variables for each year. Descriptive statistics indicate that the variables are fairly homogenous throughout the sample, because the means are higher than the standard deviations, except for the percentage of domestic brands.

The dimensions of the indicator generally have a positive and significant correlation with the number of brands per capita, the age of the association and first franchise, and the percentage of domestic brands.

\section{Estimation method}

To test the hypothesis regarding the influence of franchising on country development, we formulate the following relationship:

$$
\begin{aligned}
\text { Development }_{i t}= & f\left(\text { Franchising Extensive Margin }_{i t},\right. \text { Franchising Intensive Margin } \\
& \text { Percentage of Domestic Brands } \left.{ }_{i t}, \mu\right),
\end{aligned}
$$


IJOEM

\begin{tabular}{lcc}
\hline Variable & Mean & Std. dev. \\
\hline Development Index (DI) & 0.55 & 0.32 \\
Economic dimension & 0.56 & 0.23 \\
Social dimension & 0.61 & 0.28 \\
Institutional dimension & 0.63 & 0.26 \\
Infrastructural dimension & 0.51 & 0.28 \\
Brands per capita & $2.67 \mathrm{E}-05$ & $2.43 \mathrm{E}-05$ \\
Age of the association & 19.64 & 12.83 \\
Age of the franchising & 47.23 & 30.81 \\
Turnover per unit & 0.65 & 0.22 \\
Domestic brands percentage & 0.00 & 0.01 \\
\hline
\end{tabular}

Table 4.
Summary statistics

\begin{tabular}{|c|c|c|c|c|c|c|c|c|c|c|}
\hline Variable & (1) & (2) & (3) & (4) & (5) & (6) & (7) & (8) & (9) & (10) \\
\hline Development Index - DI (1) & 1 & & & & & & & & & \\
\hline Economic dimension (2) & $0.85^{*}$ & 1 & & & & & & & & \\
\hline Social dimension (3) & $0.94^{*}$ & $0.74^{*}$ & 1 & & & & & & & \\
\hline Infrastructural dimension (4) & $0.96^{*}$ & $0.78^{*}$ & $0.89^{*}$ & 1 & & & & & & \\
\hline Institutional dimension (5) & $0.95^{*}$ & $0.80^{*}$ & $0.81^{*}$ & $0.89^{*}$ & & & & & & \\
\hline Brands per capita (6) & $0.53^{*}$ & $0.37^{*}$ & $0.51^{*}$ & $0.50^{*}$ & $0.54^{*}$ & 1 & & & & \\
\hline Age of the association (7) & $0.58^{*}$ & $0.57^{*}$ & $0.46^{*}$ & $0.58^{*}$ & $0.58^{*}$ & 0.04 & & & & \\
\hline Age of the franchising (8) & $0.28^{*}$ & $0.40^{*}$ & $0.16^{*}$ & $0.31^{*}$ & $0.29^{*}$ & -0.05 & $0.48^{*}$ & & & \\
\hline Turnover per unit (9) & $0.28^{*}$ & $0.21^{*}$ & $0.24^{*}$ & $0.30^{*}$ & $0.26^{*}$ & $-0.12^{*}$ & $0.52^{*}$ & 0.07 & 1 & \\
\hline Domestic brands percentage (10) & 0.08 & 0.01 & 0.10 & 0.08 & 0.07 & 0.08 & -0.09 & $-0.14^{*}$ & $-0.15^{*}$ & 1 \\
\hline $\operatorname{Note}(\mathbf{s}):{ }^{*} p<0.01$ & & & & & & & & & & \\
\hline
\end{tabular}

Table 5.

Correlation matrix

where, $\mu$ is the unobserved factors, $i$ represents each country $(i=1, \ldots, 49)$, and $t$ stands for each year $(T=10)$. We propose the same empirical relationships (and the same estimation procedures) between our independent variables and each single dimension of the DI.

Because our data could be modeled with the random-effects (RE) or fixed-effects (FE) panel data estimation methods, we conducted a Hausman test for random versus fixed-effects to determine whether it would be preferable to use an $\mathrm{RE}$ or an $\mathrm{FE}$ model. For all specifications, we rejected the null hypotheses of no systematic differences between the coefficients with a $p$-value of 0 , which favored the FE. Thus, we used FE models for each equation.

$$
\begin{aligned}
\text { Development }_{i t}= & \beta_{0}+\beta_{1} \text { Franchising Extensive Margin }_{i t} \\
& +\beta_{2} \text { Franchising Intensive Margin }_{i t} \\
& +\beta_{3} \text { Domestic Brands Percentage }_{i t}+\varepsilon_{i t},
\end{aligned}
$$

where, $\varepsilon_{i t}$ stands for the within-country error.

We also considered additional alternatives of estimation, such as vector error correction, time series cross-section models, and dynamic panel data methods. The theoretical considerations of the other methods were not satisfied by our data, where our variables were a mix of stationary and nonstationary series (Beck and Katz, 1995). For robustness checks, we carried out the same regressions without the control variables along with their respective specification tests (see Tables A1 and A2 in Appendixes). 
Given the high correlation between the dependent variable, DI, and our variable of interest, extensive/intensive margin of franchising, causality might be a problem. Does development cause the appearance of new franchising brands, or does franchising lead to development? To answer this question, we used the Hausman test. Hausman (1983) stated that when a dependent variable $y$ and an independent variable $x$ are believed to be simultaneously determined, the usual econometric techniques are not consistent. Therefore, a simultaneous equation model must be estimated to take into account the causal effect of development on franchising and vice versa. If the Hausman test does not offer evidence of the existence of an endogeneity problem, we cannot reject the null hypothesis that simultaneous causality does not exist.

Given that we are using a fixed effects model, we tested for endogeneity by using a two-stage generalized least squares (2SGLS) model - the estimation results from this model are presented in Table A3. Specifically, we used the first lag of the extensive and intensive margins variables as instrumental variables; then, we carried out two tests. First, we performed the Wald test, which proved the null hypotheses of the weakness conditions of the instruments. With these tests, we confirmed that the instrumental variables used were valid for carrying out the analysis. Then, we used a Hausman test to check for the existence of an endogeneity problem. The test suggested that a systematic difference between the FGLS and the 2SGLS models did not exist, indicating the absence of endogeneity (Wooldridge, 2010) and hence rejecting the simultaneous determination of the number of extensive/intensive margins and the development level. The results for the endogeneity tests are reported in Table 6.

\section{Results}

The results of the regression analysis concerning the impact of franchising on the four dimensions of country development (economic, social, institutional and infrastructural development) are summarized in Table 7 . For robustness checks, we performed additional estimations with HDI as the dependent variable; these generally confirmed our research model (see Figure 1). As Table 6 shows, both the extensive and intensive margins of franchising are significant and have the expected positive sign in all models. This suggests that the time during which franchising has existed (extensive margin) and the intensity to which it has been used (intensive margin) in a country positively affect its development level, therefore confirming our hypotheses.

First, the findings support the positive impact of franchising (H1a), measured by extensive and intensive margins of franchising, on the economic development, operationalized by GDP, FDI, inflation and value added as percentage of GDP in the services and industry sector. Second, the empirical results support hypothesis (H1b) that franchising positively influences social development, referring to employment in different sectors, female employment, education level, infant mortality, life expectancy and public expenses. Third, the findings provide support of the positive impact of franchising on institutional development (H1c), operationalized by corruption control, government effectiveness, regulatory quality, political stability and absence of terrorism. Fourth, the empirical results confirm the positive impact of franchising on infrastructural development (H1d), consisting of electric power consumption, water source access, cellphone and broadband subscriptions, and quality of port infrastructure. To sum up, the impact of both extensive and intensive margins of franchising is significant on each dimension of our development index (DI), indicating that franchising has a positive influence not only on the economic and social development, but also on the infrastructural and institutional development of a country - aspects that are not covered by the HDI. These results are also more general than those of previous franchise studies (e.g. Kaufmann and Leibenstein, 1988; Michael, 2014).
Franchising and country development

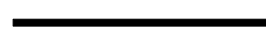




\section{IJOEM}

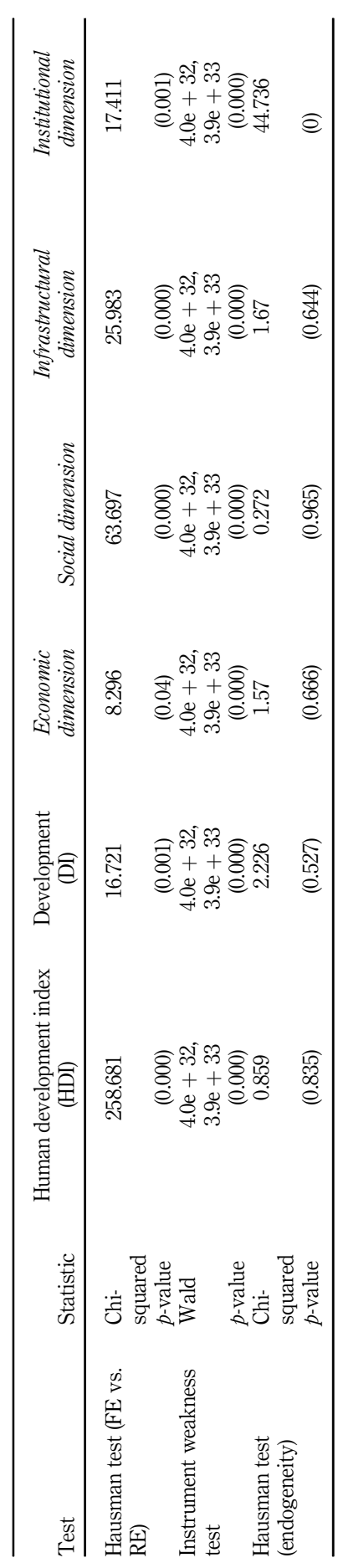

Table 6.

Specification tests for the fixed effects model 


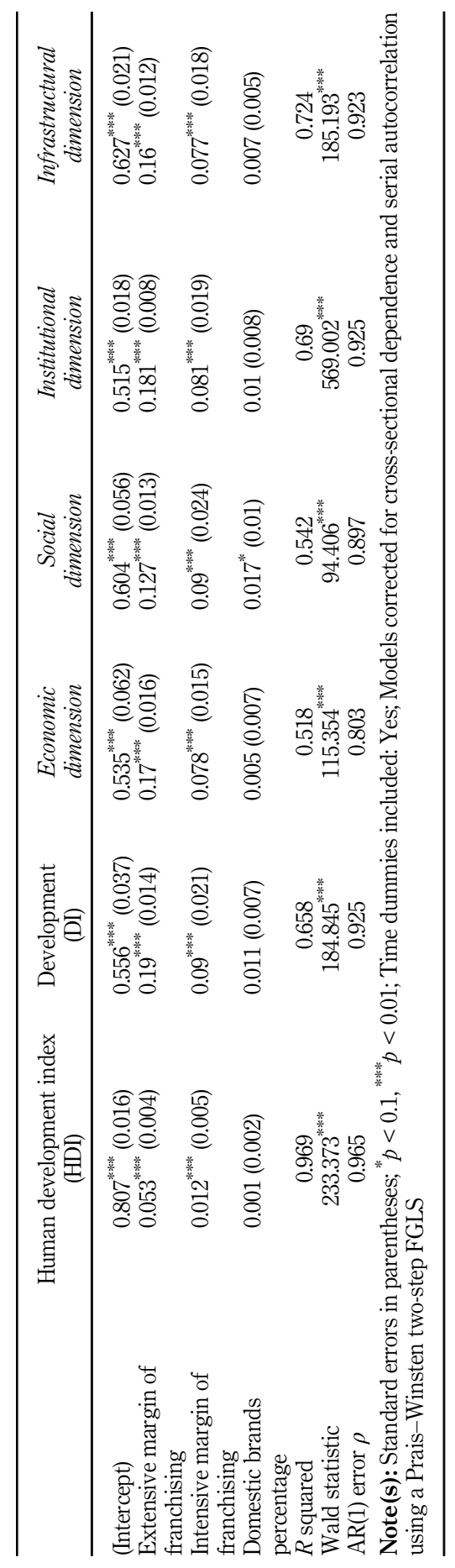

Franchising and country development 


\section{Discussion and implications}

Kaufmann and Leibenstein (1988) highlighted the importance of franchising for the creation of retail know-how in developing countries. Recently, Michael (2014) provided empirical evidence that franchising in promoting the transfer of know-how to developing countries drives economic development in Latin America. In view of previous research results in the sustainable entrepreneurship literature and the criticism of $\mathrm{HDI}$, this study uses a more comprehensive development concept that includes four dimensions: economic, social, institutional and infrastructural development. We argue that the role of franchising for country development refers not only to the economic but also to the social, institutional, and infrastructural development of the country. Based on data from 49 countries, our findings highlight that franchising has a positive impact on the economic, social, institutional, and infrastructural development of a country.

Specifically, our results highlight that the earlier and the more franchise systems enter a country, the stronger is the positive impact of franchising on the country's economic, social, institutional, and infrastructural development. In other words, countries with many years of franchise experience and a strong franchise sector (i.e. with a large number of franchise brands) can realize first-mover advantages and hence a stronger positive effect of franchising on their economic, social, institutional and infrastructural development than countries with less franchise experience and a small number of franchise brands. In addition, if we compare the impact of the extensive margin of franchising (years of franchise experience in a country) with the intensive margin of franchising (number of the franchise brands per capita and unit turnover) on development, the results show that franchise experience has a stronger impact on the economic, social, institutional, and infrastructural development of a country than the intensity of franchising (see Table 7). Therefore, countries with more franchise experience can realize stronger spillover effects of franchising due to first mover advantages than countries with less franchise experience, i.e. with a younger franchise sector. Overall, we can conclude that the positive impact of franchising on the economic, social, institutional and infrastructural development of a country increases with the level of development of a country's franchise sector.

\section{Implications for theory and practice}

This study makes two important contributions to the franchise and development literature. First, we extend the existing literature on the impact of franchising on country development by testing a development concept that goes beyond the economic dimension of development used in previous research. In addition to the role of franchisor in contributing to the economic development of a country, franchising promotes the well-being and development of the people of a country, for instance by improving the standard of living, healthcare services, education and alleviating poverty. Furthermore, the franchisor as an institutional and political entrepreneur (Dean and McMullen, 2007; Battilana et al., 2009; Li et al., 2006) is important for initiating institutional changes (e.g. regulation and legal rules in developing countries) and infrastructural projects that improve the business environment and consequently - via positive spillover effects -the public welfare. Therefore, franchising offers an opportunity for economic, social, institutional, and infrastructural development, which is particularly important for emerging and developing countries. Second, our study contributes to the literature by applying a new development concept, comprising economic, social, institutional, and infrastructural dimensions, to examine the influence of franchising on development in 49 countries from 2006 to 2015. Compared with the HDI, which mainly covers the economic and social dimension of country development, our DI incorporates institutional and infrastructural dimensions, which are particularly important for highlighting the role of the franchisor as an institutional and political entrepreneur in emerging and developing countries. 
What are the practical implications of the results of this study for the role of franchising in the development of emerging and developing economies? Because public policy in emerging and developing countries suffers from a lack of financial resources to improve the social, infrastructural and institutional environment, entrepreneurs, such as franchisors who expand into these countries, play an important role for these countries' development. In addition to their entrepreneurial role of exploring and exploiting profit opportunities, they are social, institutional, and political entrepreneurs who may positively influence country development (Dean and McMullen, 2007; Schaltegger and Wagner, 2011). Specifically, the findings highlight that countries with an older franchise sector (more years of franchise experience) may realize first-mover advantages and hence larger positive spillover effects on their economic, social, institutional and infrastructural development than countries with a younger franchise sector. Hence, governments of emerging and developing countries have the opportunity and responsibility to reduce potential market entry barriers and provide additional incentives for franchise systems in order to trigger these positive spillover effects. We expect that the spillover effects from the franchise sector on the economic, institutional, social and infrastructural development of a country are stronger in emerging and developing countries than in developed countries. Future research should shed some light on this important issue.

\section{Limitations}

This study has several limitations that provide directions for further research. First, the empirical investigation is limited by the characteristics of the data, which are composed of information from 49 countries (covering a period of 10 years). Because franchising is not recognized as a form of entrepreneurial governance in many emerging and developing countries, the available information is mainly provided by the franchise associations in the various countries. Hence, there is a need to collect additional data in each country and to include additional countries. Second, although we included developed and developing countries in our analysis, we could not differentiate between developed and developing countries when testing our hypotheses, because our database was not sufficiently complete. Third, future studies should analyze the causality issue between franchising and development more closely. The role of franchising in development may be changing depending on different unobserved country factors, economic sector characteristics, or development stages.

Fourth, our approach could be extended by including additional development dimensions. An important issue whose elucidation could add to the franchise and development literature is the link between franchising as an entrepreneurial activity and environmental development (Dean and McMullen, 2007; Hall et al., 2010). Because franchising can be a cause of and a solution to environmental problems (Tezanos and Sumner, 2013; Dhari and Omri, 2018), it is important that future research examines the role of the franchisor as an environmental and institutional entrepreneur who transfers environmentally friendly technology and practices to incumbent firms and "creates institutions to encourage incentives for reducing environmental degradation” (Lenox and York, 2011, p. 78).

\section{Conclusion}

Although previous research has examined the role of franchising for the economic development of a country, no empirical study to date has investigated the importance of franchising for social, institutional and infrastructural development. We extend the existing literature on the impact of franchising on country development by going beyond its role for the economy. Applying research results from the field of sustainable entrepreneurship, this study shows that franchising has a positive impact on the economic, social, institutional and
Franchising and country development

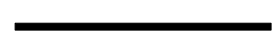


infrastructural development of a country. The findings of this study contribute to the international franchise and development economics literature by providing a better understanding of the impact of franchising on country development. From a country development perspective, we can conclude that strengthening franchising as an entrepreneurial activity offers an opportunity for governments to improve the economic, social, institutional, and infrastructural development of countries.

\section{Note}

1. We first considered multiple imputation for this task. Nevertheless, given that this method only has validity when the data are missing at random (i.e. when the probability of no response depends on the observed variables), we discarded it because our data did not satisfy condition.

\section{References}

Acs, Z.J. and Audretsch, D.B. (1988), "Innovation in large and small firms", American Economic Review, Vol. 78, pp. 678-690.

Acs, Z.J., Brauerhjelm, P., Audretsch, D. and Carlsson, B. (2009), "The knowledge spillover theory of entrepreneurship”, Small Business Economics, Vol. 32, pp. 15-30.

Acs, Z., Estrin, S., Mickiewicz, T. and Szerb, L. (2018), "Entrepreneurship, institutional economics, and economic growth: an ecosystem perspective”, Small Business Economics, Vol. 51, pp. 501-514.

Ahmad, Z. and Saleem, A. (2014), "Impact of governance on human development", Pakistan Journal of Commerce and Social Sciences, Vol. 8, pp. 612-628.

Ajayi, L. and Oke, M. (2012), "Effect of external debt on economic growth and development of Nigeria”, International Journal of Business and Social Science, Vol. 3 No. 12, pp. 297-304.

Algraini, S. (2019), "Education for human development: a capability perspective in Saudi public education", Compare: A Journal of Comparative and International Education, Vol. 51 No. 4, pp. 1-17, doi: 10.1080/03057925.2019.1629275.

Alon, I. (2004), "Global franchising and development in emerging and transitioning markets", Journal of Marcomarketing, Vol. 24, pp. 156-167.

Alon, I. (2006), Service Franchising: A Global Perspective, Springer.

Alon, I. and Banai, M. (2000), "Executive insights: franchising opportunities and threats in Russia", Journal of International Marketing, Vol. 8, pp. 104-119.

Alon, I., Mitchel, M.C. and Munoz, J.M. (2010), "Microfranchising in less developed countries", in Franchising Globally, Palgrave Macmillan, London, pp. 155-180.

Alon, I., Apriliyanti, I.D. and Henriquez Parodi, M.C. (2021), "A systematic review of international franchising”, Multinational Business Review, Vol. 29 No. 1, pp. 43-69, doi: 10.1108/MBR-012020-0019.

Altun, R.K. (2016), The Effect of Political Stability and Governance on Economic development, July 13, 2016, doi: 10.2139/ssrn.2948652.

Anand, S. and Kanbur, M. (1993), "Inequality and development a critique", Journal of Development Economics, Vol. 41 No. 1, pp. 19-43.

Anand, P. and Sen, A.K. (1994), "Human development index: methodology and measurement", HDR, available at: http://hdr.undp.org/en/content/human-development-index-methodology-andmeasurement.

Apurv, R. and Uzma, S.H. (2020), "The impact of infrastructure investment and development on economic growth on BRICS", Indian Growth and Development Review, Vol. 14 No. 1, pp. 122-47, doi: 10.1108/IGDR-01-2020-0007.

Audretsch, D.B., Heger, D. and Veith, T. (2015), "Infrastructure and entrepreneurship", Small Business Economics, Vol. 44, pp. 219-230. 
Battilana, J., Leca, B. and Boxenbaum, E. (2009), "How actors change institutions: towards a theory of institutional entrepreneurship", Academy of Management Annals, Vol. 3 No. 1, pp. 65-107.

Beck, N. and Katz, J. (1995), "What to do (and not to do) with Time-Series Cross-Section Data", The American Political Science Review, Vol. 89, pp. 634-647.

Besedes, T. and Prusa, T.J. (2011), "The role of extensive and intensive margins and export growth", Journal of Development Economics, Vol. 96 No. 2, pp. 371-379.

Blair, R. and Lafontaine, F. (2005), The Economics of Franchising, Cambridge University Press, Cambridge, MA.

Blundell, R., Bozio, A. and Laroque, G. (2011), "Labor supply and the extensive margin", American Economic Review, Vol. 101 No. 3, pp. 482-486.

Blundell, R., Bozio, A. and Laroque, G. (2013), "Extensive and intensive margins of labour supply: working hour in the US, UK and France", Fiscal Studies, Vol. 34, pp. 1-29.

Boettke, P. and Subrick, J. (2003), "Rule of law, development, and human capabilities", Supreme Court Economic Review, Vol. 10, pp. 109-126.

Bollen, K.A. and Lennox, R. (1991), "Conventional wisdom on measurement: a structural equation perspective", Psychological Bulletin, Vol. 110, pp. 305-324.

Bowman, B., Matzopoulos, R., Butchart, A. and Mercy, J.A. (2008), "The impact of violence on development in low- to middle-income countries", International Journal of Injury Control and Safety Promotion, Vol. 15 No. 4, pp. 209-19.

Bretos, I., Diaz-Foncea, M. and Marcuello, C. (2020), "Internationalization expansion of social enterprises as a catalyst for scaling up social impact across borders", Sustainability, Vol. 12, pp. 1-22.

Brinkman, R. and Brinkman, J. (2011), "GDP as a measure of progress and human development: a process of conceptual evolution”, Journal of Economic Issues, Vol. 45 No. 2, pp. 447-456.

Bruno, M. and Easterly, W. (1998), "Inflation crises and long-run growth", Journal of Monetary Economics, Vol. 41 No. 1, pp. 3-26.

Buvinic, M. and Morrison, A. (1999), Violence as an Obstacle to Development, Inter-American Development Bank, Washington, DC, pp. 1-8, Technical Note 4: Economic and social consequences of violence.

Calderón, C. and Servén, L. (2004), The Effects of Infrastructure Development on Growth and Income Distribution, The World Bank, Washington, doi: 10.1596/1813-9450-3400.

Cernich, N., Falck, O., Kretschmer, T. and Woessmann, L. (2011), "Broadband infrastructure and economic growth", The Economic Journal, Vol. 121, pp. 505-532.

Chabbott, C. and Ramirez, F.O. (2000), "Development and education”, in Hallinan, M.T. (Ed.), Handbooks of Sociology and Education, Springer, Boston, MA, doi: 10.1007/0-387-36424-2_8.

Chowdhury, F., Audretsch, D.B. and Belitski, M. (2019), "Institutions and entrepreneurship quality", Entrepreneurship Theory and Practice, Vol. 43, pp. 51-81.

Choy, C.L. and Goh, M. (1997), "Franchising - a vehicle for entrepreneurship development in Singapore", Small Enterprise Development, Vol. 8, pp. 47-53.

Christensen, L.J., Parsons, H. and Fairbourne, J. (2010), "Building entrepreneurship in subsistence markets: microfranchising as an employment incubator", Journal of Business Research, Vol. 63, pp. 595-601.

Coulibaly, S., Erbao, C. and Mekongcho, M. (2018), "Economic globalization, entrepreneurship, and development", Technological Forecasting and Social Change, Vol. 127, pp. 271-280.

Croonen, E., Brand, M. and Huizingh, E. (2016), "To be entrepreneurial, or not to be entrepreneurial? Explaining differences in franchisee entrepreneurial behavior within a franchise system", International Entrepreneurship Management Journal, Vol. 12, pp. 531-553.

Dean, T.J. and McMullen, J.S. (2007), "Toward a theory of sustainable entrepreneurship: reducing environmental degradation through entrepreneurial action", Journal of Business Venturing, Vol. 22, pp. 50-76.
Franchising and country development

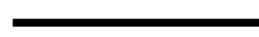


Dhahri, S. and Omri, A. (2018), "Entrepreneurship contribution to the three pillars of sustainable development", World Development, Vol. 106, pp. 64-77.

Diamantopoulos, A. and Winkler, H.M. (2001), "Index construction with formative indicators: an alternative to scale development", Journal of Marketing Research, Vol. 38, pp. 269-277.

Diamantopoulos, A., Riefler, P. and Roth, K.P. (2008), "Advancing formative measurement models”, Journal of Business Research, Vol. 61, pp. 1203-1218.

Du Toit, A. (2017), “An introduction to social franchising”, in Hoy, F., Perrigot, R. and Terry, A. (Eds), Handbook of Research on Franchising, Edward Elgar Publishing, Cheltenham.

Fairbourne, J.S., Gibson, S.W. and Dyer, W.G. (2007), Microfranchising: Creating Wealth at the Bottom of the Pyramid, Edward Elgar Publishing, Northhampton.

Fayers, P.M., Hand, D.J., Bjordal, K. and Groenvold, M. (1997), "Causal indicators in quality of life research", Quality of Life Research, Vol. 6, pp. 393-406.

Fredriks, J.W.S. and Pennink, B.J.W. (2014), "Modelling a technology push by using hybrid franchising", International Journal of Entrepreneurship and Small Business, Vol. 22, pp. 62-88.

Ganegodage, K.R., Rambaldi, A.N. and Rao, D.S.P. (2017), "A new multidimensional measure of development: the role of technology and institutions", Social Indicators Research, Vol. 131, pp. 65-92.

Goetz, A. and Jenkins, R. (2002), "Voice, accountability and human development: the emergence of a new agenda", Human Development Occasional Papers HDR 2002.

Goldman, A. (1974), "Outreach of consumers and the modernization of urban food retailing in developing countries", Journal of Marketing, Vol. 38 No. 4, pp. 8-16.

Goldman, A. (1981), "Transfer of a retailing technology into the less developed countries: the supermarket case", Journal of Marketing, Vol. 57, pp. 5-28.

Goldman, A. (2001), "The transfer of retail formats into developing economies: the example of China", Journal of Retailing, Vol. 77, pp. 221-242.

Hall, J.K., Daneke, G.A. and Lenox, M.J. (2010), "Sustainable development and entrepreneurship: past contributions and future directions", Journal of Business Venturing, Vol. 25, pp. 439-448.

Haller, A.P. (2012), "Concepts of economic growth and development challenges of crisis and of knowledge", Economy Transdisciplinarity Cognition, Vol. 15, pp. 66-71.

Haque, M.E. (2004), "The composition of public expenditures and economic growth in developing countries", Global Journal of Finance and Economics, Vol. 1 No. 1, pp. 97-117.

Hausman, J. (1983), "Specification and estimation of simultaneous equation models", in Griliches, Z. and Intriligator, M. (Eds), Handbook of Econometrics, North-Holland Publishing Company.

Hermes, N. and Lensink, R. (2003), "Foreign direct investment, financial development and economic growth", The Journal of Development Studies, Vol. 40 No. 1, pp. 142-163.

Hessel, J. and Naudé, W. (2017), "The intersection of the fields of entrepreneurship and development economics: a review towards a new view", Discussion Paper, IZA Institute of Labor Economics, October 2017.

Hwang, H. and Powell, W. (2006), "Institutions and entrepreneurship", in Alvarez, S., Agarwal, R. and Soerensen, O. (Eds), Handbook of Entrepreneurship Research, Springer, New York, pp. 201-232.

Islam, S. and Clarke, M. (2002), "The relationship between economic development and social welfare: a new adjusted GDP measure of welfare”, Social Indicators Research, Vol. 57 No. 2, pp. 201-228.

Jell-Ojobor, M. and Windsperger, J. (2014), "The choice of governance modes of international franchise firms: development of an integrative model", Journal of International Management, Vol. 20, pp. 153-187.

Johnson, M.P. and Schaltegger, S. (2020), "Entrepreneurship for sustainable development: a review and multilevel causel mechanism framework", Entrepreneurship Theory and Practice, Vol. 44, pp. 1141-1173. 
Kaufmann, P. and Leibenstein, H. (1988), "International business format franchising and retail entrepreneurship: a possible source of retail know-how for developing countries", Journal of Development Planning, Vol. 18, pp. 165-179.

Ketchen, D., Short, J. and Combs, J. (2011), "Is franchising entrepreneurship? Yes, no, and maybe so", Entrepreneurship Theory and Practice, Vol. 35 No. 3, pp. 583-593.

Kovacevic, M. (2011), "Review of HDI critiques and potential improvements", Human Development Research Paper, 2010/33, available at: http://hdr.undp.org/en/content/review-hdi-critiques-andpotential-improvements.

Leibenstein, H. (1968), "Entrepreneurship and development", American Economic Review, Vol. 58, pp. 72-83.

Lenox, M. and York, J.G. (2011), "Environmental entrepreneurship", in Hoffman, A.J. and Bansal, T. (Eds), Oxford Handbook of Business and the Environment, Oxford University Press, Oxford, pp. 70-82.

Li, D.D., Feng, J. and Jiang, H. (2006), "Institutional entrepreneurs", American Economic Review, Vol. 96, pp. 358-362.

Mamo, N., Bhattacharyya, S. and Moradi, A. (2019), "Intensive and extensive margin of mining and development: evidence from Sub-Saharan Africa", Journal of Development Economics, Vol. 139, pp. $28-49$.

McGrath, S. (2010), "Education and development: thirty years of continuity and change", International Journal of Educational Development, Vol. 30, pp. 537-543.

Michael, S. (2014), "Can franchising be an economic development strategy for developing nations? An empirical investigation", Small Business Economics, Vol. 42, pp. 611-620.

Michelis, L. and George, K. (2004), "Exports, imports and GDP growth: causal relations in six European Union countries", The Journal of Economic Asymmetries, Vol. 1, pp. 71-85.

Montagu, D. (2002), "Franchising in health services in low-income countries", Health Policy and Planning, Vol. 17 No. 2, pp. 121-130.

Moran, T.H. (2012), "Foreign direct investment and development", in Ritzer, G. (Ed.), The WileyBlackwell Encyclopedia of Globalization, doi: 10.1002/9780470670590.wbeog217.

Morris, I. (2010), Why the West Rules-For Now: The Patterns of History, and what They Reveal about the Future, Farrar, Straus and Giroux, New York.

Mungiu-Pippidi, A. and Hartmann, T. (2019), "Corruption and development: a reappraisal", Oxford Research Encyclopedia of Economics and Finance, available at: https://oxfordre.com/economics/ view/10.1093/acrefore/9780190625979.001.0001/acrefore-9780190625979-e-237.

Naatu, F. and Alon, I. (2019), "Social franchising: a bibliometric and theoretical review", Journal of Promotion Management, Vol. 25, pp. 738-764.

Naatu, F., Alon, I. and Uwamahoro, R. (2020), "Micro-franchising in the bottom of the pyramid market: Rwanda”, Journal of Social Entrepreneurship, pp. 1-21, doi: 10.1080/19420676.2020.1755347.

Naudé, W. (2013), "Entrepreneurship and economic development: theory, evidence and policy", Institute for the Study of Labor, available at: https://ideas.repec.org/p/iza/izadps/dp7507.html.

Prieger, J., Bampoky, C., Blanco, L. and Liu, A. (2016), "Economic growth and the optimal level of entrepreneurship”, World Development, Vol. 82, pp. 95-109.

Prud'homme, R. (2005), "Annual world bank conference on development economics 2005: lessons of experience”, World Bank, available at: https://books.google.com.ec/books?id=HwXGf4CRq7gC.

Rodrik, D. (2014), “The past, present, and future of economic growth”, Challenge, Vol. 57, pp. 5-39.

Rosado-Serrano, A., Paul, J. and Dikova, D. (2018), "International franchising: a literature review and research agenda", Journal of Business Research, Vol. 85, pp. 238-257.

Ruger, J.P. (2003), "Health and development", The Lancet, Vol. 362, p. 678, doi: 10.1016/S0140-6736(03) 14243-2https://doi.org/10.1016/S0140-6736(03)14243-2. 
Sánchez, P. and Prado, A. (2015), "Del concepto de crecimiento económico al de desarrollo de las naciones: una aplicación a la Unión Europea”, Revista de Economía Mundial, Vol. 40, pp. 251-252.

Sadequl, I. (1995), "The human development index and per capita GDP”, Applied Economics Letters, Vol. 2 No. 5, pp. 166-167.

Salama, P. (2009), "Development and inequalities", Brazilian Journal of Political Economy, Vol. 29 No. 4, pp. 377-385.

Sawada, S., Shoji, M. and Shinka, N. (2014), "The role of infrastructure in mitigating poverty dynamics: the case of an irrigation project in Sri Lanka", Journal of Economic Analysis and Policy, Vol. 14, pp. 1-28.

Schaltegger, S. and Wagner, M. (2011), "Sustainable entrepreneurship and sustainability innovation: categories and interactions", Business Strategy and the Environment, Vol. 20, pp. 22-37.

Seers, D. (1969), “The meaning of development”, International Development Review, Vol. 11, pp. 2-6.

Seers, D. (1972), "What are we trying to measure?", Journal of Development Studies, Vol. 8 No. 3, pp. 21-36.

Sen, A.K. (1980), "Equality of what?", in McMurrin S. Tanner Lectures on Human Values, Cambridge University Press, Cambridge, Vol. 1.

Shepard, D.A. and Patzelt, H. (2011), "The new field of sustainbale entrepreneurship: studying entrepreneurial action linking 'what is to be sustained' with 'what is to be developed"', Entrepreneurship Theory and Practice, Vol. 35, pp. 137-163.

Solt, F. (2016), "The standardized world income inequality database”, Social Science Quarterly, Vol. 97, pp. 1267-1281.

Stadler, M., Sailer, M. and Fischer, F. (2021), "Knowledge as formative construct: a good alpha is not always better", New Ideas in Psychology, Vol. 60, doi: 10.1016/j.newideapsych.2020.100832.

Stanworth, J., Purdy, D. and Price, S. (2003), "Franchising as a source of technology transfer to developing countries", in Welsh, D. and Alon, I. (Eds), International Franchising in Industrialized Markets: Western and North Europe, CCH, Chicago, pp. 87-103.

Stewart, F. and Samman, E. (2014), Inequality and Development: an Overview, doi:10.1093/acprof:oso/ 9780199671656.003.0007.

Sumner, A. and Tribe, M. (2008), "International development studies: theories and methods in research and practice", available at: https://us.sagepub.com/en-us/sam/international-developmentstudies/book229881\#description.

Taner, M., Sezen, B. and Mihc1, H. (2011), "An alternative human development index considering unemployment", South East European Journal of Economics and Business, Vol. 6 No. 1, pp. $45-60$.

Tezanos Vázquez, S. and Sumner, A. (2013), "Revisiting the meaning of development: a multidimensional taxonomy of developing countries", Journal of Development Studies, Vol. 49 No. 12, pp. 1728-1745.

Umaru, A., Zubairu, A.A. and Adama, M. (2012), "Effect of inflation on the growth and development of the Nigerian economy (An empirical enalysis)", International Journal of Business and Social Science, Vol. 3 No. 10, pp. 183-191.

UNDP (United Nations Development Programme) (1990, 2006-2015), Human Development Report, Oxford University Press, New York.

Urbano, D. and Aparicio, S. (2016), "Entrepreneurship capital types and economic growth: international evidence", Technological Forecasting and Social Change, Vol. 102, pp. 34-44.

Van Praag, C.M. and Versloot, P.H. (2008), "The economic benefits and costs of entrepreneurship: a review of the research", Foundations and Trends in Entrepreneurship, Vol. 4, pp. 63-152.

Waterbury, J. (1976), "Corruption, political stability and development: comparative evidence from Egypt and Morocco", Government and Opposition, Vol. 11 No. 4, pp. 426-445. 
Wennekers, S. and Thurik, R. (1999), "Linking entrepreneurship and economic growth", Small Business Economics, Vol. 13, pp. 27-55.

Wooldridge, J. (2010), Econometric Analysis of Cross Section and Panel Data, The MIT Press, Cambridge, MA.

Woolley, J.L. (2013), "The creation and configuration of infrastructure for entrepreneurship in emerging domains of activity", Entrepreneurship Theory and Practice, Vol. 38, pp. 721-747.

\section{Further reading}

Hoffman, R., Munemo, J. and Watson, S. (2016), "International franchise expansion: the role of institutions and transaction costs", Journal of International Management, Vol. 22, pp. 101-114.

Otusanya, O. (2011), "Corruption as an obstacle to development in developing countries: a review of literature", Journal of Money Laundering Control, Vol. 14 No. 4, pp. 387-422.

Sánchez, I., Cuadrado-Ballesteros, B. and Frias-Aceituno, J.-V. (2013), "Determinants of government effectiveness", International Journal of Public Administration, Vol. 36, doi: 10.1080/01900692. 2013.772630.

\section{Corresponding author}

Josef Windsperger can be contacted at: josef.windsperger@univie.ac.at
Franchising and country development 
IJOEM

\section{Table A1.}

Estimation results for the FE models without control variables

\section{Appendixies}

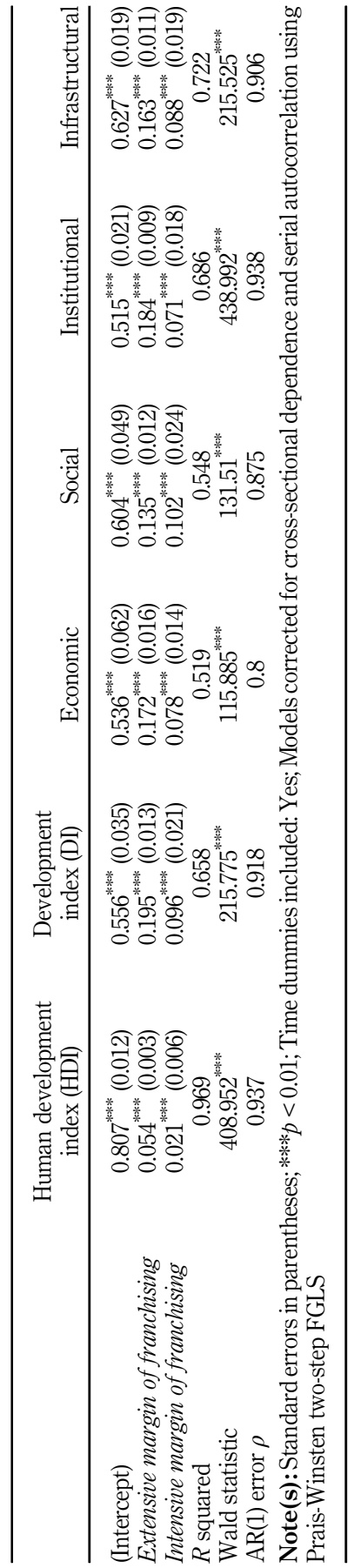




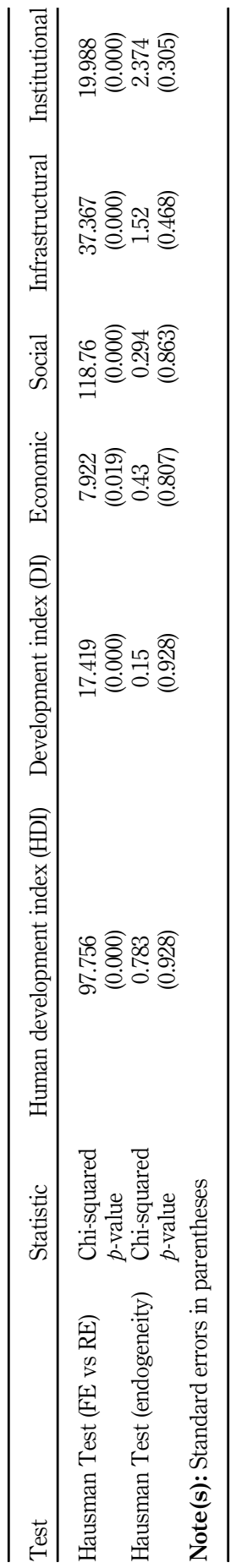

Franchising and country development 


\section{IJOEM}

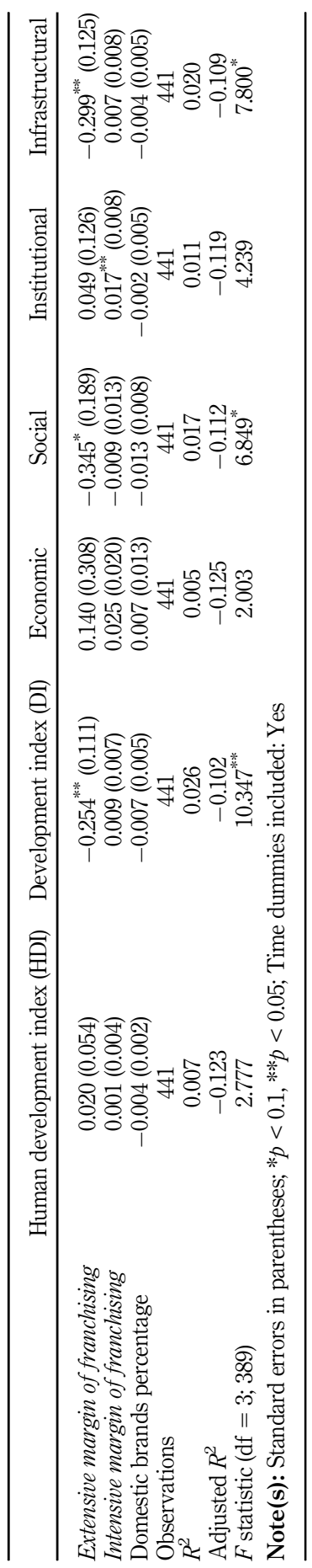

Table A3.

Two-stage regressions

. 